\title{
PENGARUH KONSENTRASI DAN LAMA PERENDAMAN BAHAN DENGAN ASAM LAKTAT SEBELUM PENGERINGAN TERHADAP KARAKTERISTIK BUBUK BUNGA KENIKIR (Tagetes erecta L.)
} \author{
Effect of Lactic Acid Concentration and Maceration Time before Drying on Characteristics of
} Flower Powder (Tagetes erecta L.)

\author{
Made Wahyu Nadaiswara Putra, Ni Made Wartini*, Lutfi Suhendra, \\ PS Teknologi Industri Pertanian, Fakultas Teknologi Pertanian, Universitas Udayana, Kampus Bukit \\ Jimbaran, Badung, Kode pos : 80361; Telp/Fax : (0361) 701801.
}

Diterima 13 November 2018 / Disetujui 08 Januari 2019

\begin{abstract}
Marigold flowers (Tagetes erecta L.) have the potential as natural dyes that contain color pigments from carotenoid compounds. The purpose of this study was to determine the effect of lactic acid concentration and soaking time before drying on the characteristics of kenikir flower powder and determine the concentration of lactic acid and the duration of lactic acid immersion before the best combustion to produce kenikir flower powder. This study used a randomized block design using factorial patterns with 2 factors. The first factor is the concentration of lactic acid consisting of 3 levels: 0,5, 1,0, and 1,5\%. The second factor is the immersion time consisting of 3 levels: 60, 90, and 120 minutes. The results showed that the treatment of lactic acid concentration affected the total carotenoid level, brightness $(L *)$, redness level $(a *)$ yellowish level $(b *)$ but did not significantly affect the water content. The treatment of immersion time did not affect the total carotenoid level, brightness level $\left(L^{*}\right)$, yellowish level $\left(a^{*}\right)$, redness level $\left(b^{*}\right)$ and water content. Immersion treatment with a concentration of $1,5 \%$ and 90 minutes soaking time is the best treatment for producing kenikir flower powder with characteristics namely water content $16,71 \%$, total carotenoid content $18,77 \%$, brightness level ( $\left.L^{*}\right) 38,23$, redness level ( $a *)$ 29,02, yellowish level ( $b *)$ 51,93.
\end{abstract}

Keywords : Tagetes erecta L., lactic acid, karotenoid, color

\begin{abstract}
ABSTRAK
Bunga kenikir marigold (Tagetes erecta L.) berpotensi sebagai pewarna alami yang mengandung pigmen warna dari senyawa karotenoid. Tujuan penelitian ini adalah untuk mengetahui pengaruh konsentrasi asam laktat dan lama perendaman sebelum pengeringan terhadap karakteristik bubuk bunga kenikir, menentukan konsentrasi asam laktat dan lama perendaman asam laktat sebelum pengerimgan terbaik untuk menghasilkan bubuk bunga kenikir. Penelitian ini menggunakan Rancangan Acak Kelompok menggunakan pola faktorial dengan 2 faktor. Faktor pertama adalah konsentrasi asam laktat terdiri dari 3 taraf yaitu: $0,5,1,0$, dan $1,5 \%$. Faktor kedua adalah lama perendaman terdiri dari 3 taraf yaitu: 60, 90, dan 120 menit. Hasil penelitian menunjukan Perlakuan konsentrasi asam laktat berpengaruh terhadap kadar total karotenoid, tingkat kecerahan ( $\left.\mathrm{L}^{*}\right)$, tingkat kemerahan (a*) tingkat kekuningan $\left(\mathrm{b}^{*}\right)$ tetapi tidak berpengaruh nyata terhadap kadar air. Perlakuan lama perendaman tidak berpengaruh terhadap kadar total karotenoid, tingkat kecerahan $\left(\mathrm{L}^{*}\right)$, tingkat kekuningan $\left(\mathrm{a}^{*}\right)$, tingkat
\end{abstract}

*Korespondensi Penulis:

Email : md_wartini@unud.ac.id 
kemerahan $\left(b^{*}\right)$ dan kadar air. Perlakuan perendaman dengan konsentrasi 1,5\% dan lama perendaman 90 menit merupakan perlakuan terbaik untuk menghasilkan bubuk bunga kenikir dengan karakteristik yaitu kadar air $16,71 \%$, kadar total karotenoid $18,77 \%$, tingkat kecerahan ( $\left.\mathrm{L}^{*}\right) 38,23$, tingkat kemerahan (a*) 29,02, tingkat kekuningan (b*) 51,93.

Kata Kunci : Tagetes erecta L., asam laktat, karotenoid, warna

\section{PENDAHULUAN}

Tanaman kenikir merupakan sumber pigmen berwarna kuning seperti karoten yaitu alfa dan beta karoten (Handelman, 2001). Warna kuning bunga kenikir ini disebabkan oleh dua pigmen utama, yaitu pigmen dari golongan karotenoid dan flavonoid. Ekstrak bunga kenikir mengandung sekitar $27 \%$ pigmen karotenoid, mahkota kenikir mengandung karotenoid sekitar 200 kali lebih besar dari karotenoid jagung (Vasudevan et al., 1997). Ada beberapa pewarna alami yang telah banyak digunakan oleh masyarakat antara lain yaitu dari ekstrak daun pandan, warna kuning dari kunyit, warna hijau dari daun suji dan ekstrak buah-buahan (Effendi, 2009). Pigmen yang terdapat di dalam bunga kenikir marigold digunakan sebagai pewarna makanan (Priyanka et al., 2013).

Bunga kenikir sebelum diekstraksi perlu dikeringkan terlebih dahulu dengan tujuan untuk menurunkan kadar air dan mempermudah kontak pelarut dengan bahan. Selama pengeringan terjadi penurunan karotenoid karena proses oksidasi, sehingga perlu dilakukan perlakuan pendahuluan. Perlakuan pendahuluan yang dilakukan dapat berupa blansing dan perendaman dengan asam atau basa (Prabasini et al., 2013). Perlakuan perendaman dengan asam laktat dapat menghambat kerusakan kadar karotenoid akibat reaksi oksidasi. Perlakuan perendaman memberikan pengaruh yang nyata terhadap penurunan kadar karotenoid. Penelitian yang dilakukan oleh Yanuwardana et al. (2013) tentang perendaman labu kuning dengan asam laktat, bila konsentrasi asam laktat dinaikkan dari $0,5 \%$ menjadi $1 \%$ menunjukkan pengaruh yang signifikan terhadap penghambatan kerusakan karotenoid. Namun, bila konsentrasi asam laktat dinaikkan menjadi $1,5 \%$ tidak menunjukkan pengaruh yang signifikan terhadap penghambatan kerusakan karotenoid dibandingkan dengan konsentrasi $1 \%$. Hal ini menunjukkan bahwa pada batas konsentrasi tertentu merupakan penghambat penurunan kadar karotenoid paling maksimal dan bila konsentrasi ditambahkan tidak akan memberikan pengaruh lagi pada kadar karotenoid. Pada penelitian yang dilakukan Yanuwardana et al. (2013) mengenai perendaman labu kuning dengan asam laktat diperoleh perlakuan dengan konsentrasi $1 \%$ dan lama perendaman 90 menit yang menghasilkan bubuk labu kuning dengan kadar karotenoid tertinggi. Berdasarkan hal tersebut maka pada penelitian ini digunakan konsentrasi asam laktat $0,5 \%, 1 \%$, dan $1,5 \%$ dengan lama waktu perendaman digunakan adalah 60 menit, 90 menit dan 120 menit untuk mendapatkan bubuk bunga kenikir terbaik. Tujuan penelitian ini adalah mengetahui pengaruh konsentrasi asam laktat dan lama perendaman sebelum pengeringan terhadap karakteristik bubuk bunga kenikir, menentukan konsentrasi asam laktat dan lama perendaman asam laktat sebelum pengerimgan terbaik untuk menghasilkan bubuk bunga kenikir.

\section{METODE PENELITIAN}

\section{Tempat dan Waktu Kegiatan}

Penelitian ini dilakukan di
Laboratorium Rekayasa Proses dan
Pengendalian Mutu, Laboratorium
Pengolahan Pangan, Laboratorium Analisis
Pangan Fakultas Teknologi Pertanian
Universitas Udayana. Penelitian ini


dilakukan pada Juli sampai dengan September 2018.

\section{Alat dan Bahan Penelitian}

Peralatan yang digunakan dalam penelitian yaitu bubuk bunga kenikir marigold antara lain oven (Blue M), ayakan 60 mesh (Retsch), blender (Philips), gelas ukur (Herma, Iwaki), aluminium foil, pipet tetes, magnetic stirer, $\mathrm{pH}$ meter. Peralatan yang digunakan untuk analisis antara lain timbangan analitik (SHIMADSZUATY224), Erlenmeyer (Duran), gelas beaker (Pyrex, Iwaki), penjepit, oven (Cole-Parmer, StableTemp), desikator (Duran), kertas saring kasar, color reader (Accuprobe $\mathrm{HH}-$ 06), spektrofotometer (Genesys 10S UVVIS), vortex (Barnstead Thermolyne HHMaxi Mix II), labu ukur, tabung reaksi (Iwaki), corong pisah (Pyrex), loyang, pipet volume (Iwaki)

Bahan utama pada penelitian ini yaitu bunga kenikir marigold (Tagetes erecta L.) yang diperoleh dari Desa Tua, Kecamatan Marga, Kabupaten Tabanan, Provinsi Bali dengan kriteria bunga mekar warna oranye terang dan diameter bunga 6-8 $\mathrm{cm}$. Sedangkan bahan-bahan kimia yang digunakan yaitu akuades, asam laktat dan bahan kimia untuk analisis (pa E, Merck) yaitu petroleum benzena, aseton, $\mathrm{Na}_{2} \mathrm{SO}_{4}$ anhidrat, dan bubuk $\beta$-karoten (Merck).

\section{Rancangan Percobaan}

Percobaan ini merupakan percobaan faktorial 2 faktor menggunakan Rancangan Acak Kelompok (RAK). Faktor I yaitu konsentrasi asam laktat $(\mathrm{K})$ terdiri atas 3 taraf yaitu: $\mathrm{K} 1=0,5 \%, \mathrm{~K} 2=1,0 \%, \mathrm{~K} 3=1,5 \%$, Faktor II yaitu lama perendaman (T) terdiri atas 3 taraf yaitu: $\mathrm{T} 1=60$ menit, $\mathrm{T} 2=90$ menit,T3 =120 menit. Dari 2 faktor di atas dapat diperoleh 9 kombinasi perlakuan, masing-masing perlakuan yang dilakukan 2 kali berdasarkan waktu pengerjaanya sehingga diperoleh 18 satuan percobaan. Data obyektif yang diperoleh dianalisis dengan analisis ragam apabila perlakuan berpengaruh terhadap variabel yang diamati, maka di lanjutkan dengan uji Tukey 5\% menggunakan software minitab 16. Perlakuan terbaik adalah dari perlakuan yang menghasilkan kadar karotenoid tertinggi.

\section{Pelaksanaan Penelitian}

Mahkota bunga kenikir marigold (Tagetes erecta L.) disortasi untuk memilih warna mahkota bunga yang seragam setelah itu dipisahkan dari dasar bunga. Pembuatan larutan asam laktat dilakukan dengan melarutkan asam laktat dengan air sehingga terbentuk larutan dengan konsentrasi sesuai perlakuan yaitu $0,5 \%, 1,0 \%$, dan $1,5 \%$. Dilakukan pengukuran $\mathrm{pH}$ setiap larutan. Didapat $\mathrm{pH}$ asam laktat konsentrasi $0,5 \%=$ $2,5,1,0 \%=2,4,1,5 \%=2,3$. Mahkota bunga kenikir direndam ke dalam larutan asam laktat pada perbandingan bahan dengan larutan yaitu $1: 3$ dan perendaman dilakukan selama 60, 90, dan 120 menit. Setelah dilakukan perendaman mahkota bunga kenikir ditiriskan kemudian dikeringkan menggunakan oven pada suhu $50 \pm 2^{\circ} \mathrm{C}$ sampai kadar air $12-17 \%$ dan mudah dihancurkan (Kadar air sekitar 12-17\%). Setelah mahkota bunga kering kemudian dihancurkan dan diayak dengan ayakan 60 mesh. Diagram alir pembuatan bubuk bunga kenikir ditunjukan pada Gambar 1.

\section{Variabel yang Diamati}

Variabel yang diamati pada bubuk bunga kenikir adalah: ), kadar air (Sudarmadji et al., 2003), kadar total karoten (Muchtadi, 1989), intensitas warna sistem L*, a*, b* (Weaver, 1996. 


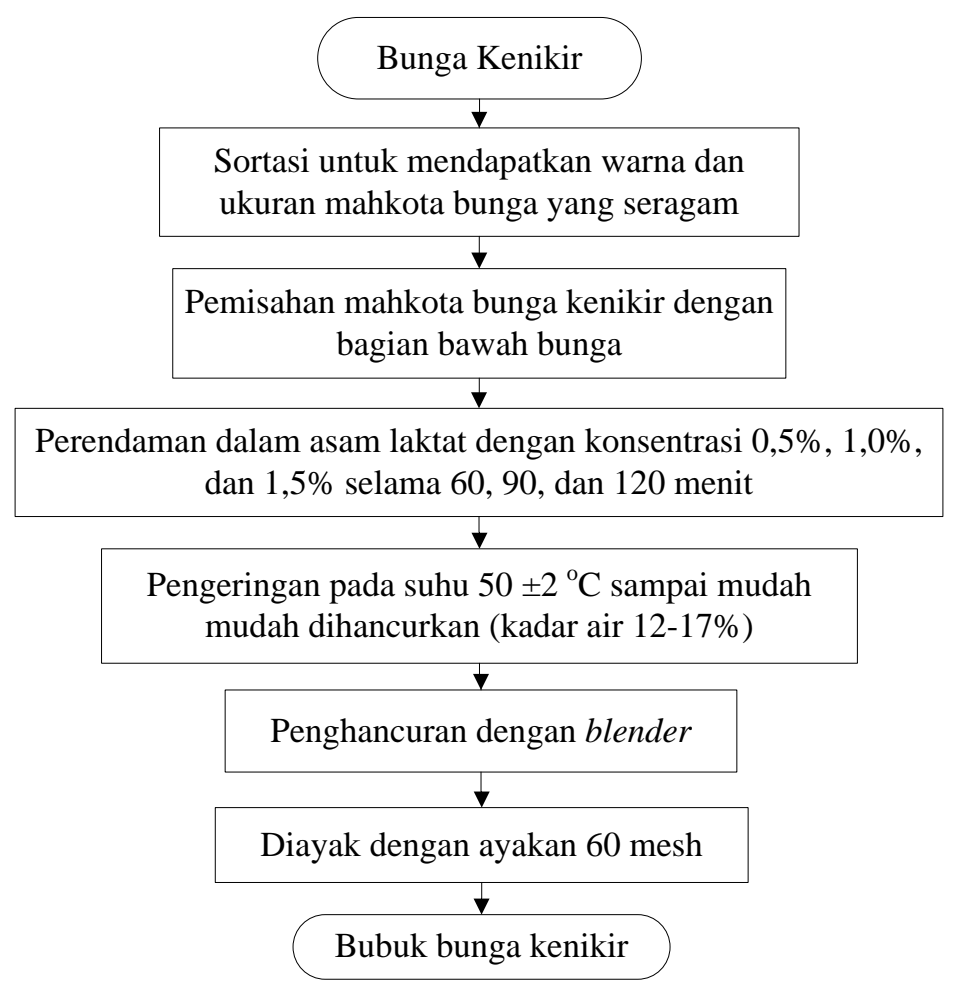

Gambar 1. Diagram alir pembuatan bubuk bunga kenikir

\section{HASIL DAN PEMBAHASAN}

\section{Kadar air}

Hasil analisis keragaman menunjukkan bahwa perlakuan konsentrasi asam laktat berpengaruh tidak nyata $(\mathrm{P}>0,05)$, sama dengan perlakuan lama perendaman juga berpengaruh tidak nyata $(\mathrm{P}>0,05)$ terhadap kadar air pada bubuk bunga kenikir. Nilai rata-rata kadar air bisa dilihat pada Tabel 1 .

Tabel 1. Nilai rata-rata kadar air (\%) pada perlakuan konsentrasi asam laktat dan lama perendaman.

\begin{tabular}{ccccc}
\hline Konsentrasi & \multicolumn{3}{c}{ Lama Perendaman (menit) } & Rata-rata \\
\cline { 2 - 5 } Asam Laktat (\%) & 60 & 90 & 120 & \\
\hline 0,5 & 12,96 & 13,40 & 16,82 & $14,39 \pm 3,04^{\text {a }}$ \\
1,0 & 14,29 & 14,16 & 13,80 & $14,09 \pm 0,81^{\text {a }}$ \\
1,5 & 14,10 & 16,71 & 14,18 & $14,99 \pm 2,69^{\text {a }}$ \\
\hline
\end{tabular}

Rata-rata $\quad 13,78 \pm 2,83^{\text {a }} \quad 14,76 \pm 0,85^{\text {a }} \quad 14,93 \pm 2,85^{\text {a }}$

Keterangan : Huruf yang berbeda di belakang nilai rata-rata pada baris atau kolom yang sama menunjukkan adanya perbedaan yang nyata $(\mathrm{P}<0,05)$.

Tabel 1 menunjukkan, kadar air pada semua perlakuan konsentrasi asam lakat berbeda tidak nyata. Perlakuan lama perendaman berpengaruh tidak nyata namun memiliki kecenderungan meningkat seiring bertambahnya lama perendaman. Hal ini dikarenakan semakin lama perendaman diduga air yang meresap menjadi semakin bertambah sehingga kadar air pada bubuk bunga kenikir menjadi meningkat.. Hasil ini didukung oleh penelitian Yanurwardana et al. (2013) mengenai perlakuan perendaman labu kuning dengan asam laktat bahwa selama perendaman terjadi penyerapan air saat 
proses perendaman yang berakibat pada penambahan jumlah air yang ada dalam labu kuning.

\section{Kadar Total Karotenoid}

Hasil analisis keragaman menunjukkan bahwa perlakuan konsentrasi asam laktat berpengaruh nyata $(\mathrm{P}<0,05)$, sedangkan perlakuan lama perendaman dan interaksi kedua perlakuan berpengaruh tidak nyata $(\mathrm{P}>0,05)$ terhadap kadar total karotenoid. Nilai rata-rata dari kadar total karotenoid dapat dilihat pada Tabel 2 .

Tabel 2. Nilai rata-rata kadar total karotenoid (\% bk) pada perlakuan konsentrasi asam laktat dan lama perendaman.

\begin{tabular}{ccccc}
\hline Konsentrasi Asam & \multicolumn{3}{c}{ Lama Perendaman (menit) } & Rata-rata (\%) \\
\cline { 2 - 5 } Laktat (\%) & 60 & 90 & 120 & \\
\hline 0,5 & 13,32 & 15,95 & 16,09 & $15,12 \pm 1,96^{\mathrm{b}}$ \\
1,0 & 15,35 & 18,00 & 17,04 & $16,80 \pm 0,95^{\text {ab }}$ \\
1,5 & 16,79 & 18,77 & 18,10 & $17,89 \pm 1,48^{\text {a }}$ \\
\hline
\end{tabular}

Rata-rata $\quad 15,16 \pm 3,30^{\mathrm{a}} \quad 17,57 \pm 0,72^{\mathrm{a}} \quad 17,08 \pm 0,38^{\mathrm{a}}$

Keterangan : Huruf yang berbeda di belakang nilai rata-rata pada baris atau kolom yang sama menunjukkan adanya perbedaan yang nyata $(\mathrm{P}<0,05)$.

Tabel 2 menunjukkan bahwa rata-rata kadar karotenoid tertinggi dihasilkan bubuk bunga kenikir yang direndam dengan larutan asam laktat konsentrasi $1,5 \%$, tetapi tidak berbeda dengan perlakuan asam laktat $1,0 \%$. Hal tersebut membuktikan bahwa perendaman dalam asam laktat dengan konsentrasi $1,0 \%$ dan $1,5 \%$ lebih efektif untuk penghambatan kerusakan karotenoid bubuk bunga kenikir, dibandingkan dengan konsentrasi $0,5 \%$. Larutan asam laktat dapat mencegah proses oksidasi pada bunga dan dapat mempertahankan karotenoid. Karena selama perendaman dengan asam laktat menyebabkan inaktivasi enzim oksigenase, monooksigenase dan lipoksigenase yang akan terdenaturasi bila ditambah asam. Ketika enzim oksigenase yang mengkatalis atau mempercepat reaksi oksidasi karotenoid tersebut rusak sehingga kehilangan fungsi sebagai enzim, maka laju kecepatan reaksi oksidasinya juga akan menurun. Hal tersebut berdampak terhadap penghambatan kerusakan karotenoid. Hasil ini didukung oleh penelitian Yanurwardana et al (2013) mengenai perlakuan perendaman memberikan pengaruh yang nyata terhadap penghambatan kadar karotenoid tepung labu kuning, baik dengan konsentrasi $0,5 \% ; 1 \%$ maupun $1,5 \%$ bila dibandingkan dengan tepung tanpa perendaman.

\section{Intensitas Warna $\left(\mathbf{L}^{*}, \mathbf{a}^{*}, \mathbf{b}^{*}\right)$ Tingkat kecerahan $\left(\mathbf{L}^{*}\right)$}

Hasil analisis keragaman menunjukkan bahwa perlakuan konsentrasi asam laktat berpengaruh nyata $(\mathrm{P}<0,05)$, sedangkan perlakuan lama perendaman dan interaksi kedua perlakuan berpengaruh tidak nyata $(\mathrm{P}>0,05)$ terhadap tingkat kecerahan $\left(\mathrm{L}^{*}\right)$ bubuk bunga kenikir marigold. Nilai ( $\left.L^{*}\right)$ menyatakan tingkat gelap sampai terang dengan kisaran $0-100$. Nilai rata-rata dari tingkat kecerahan $\left(\mathrm{L}^{*}\right)$ dapat dilihat pada Tabel 3.

Tabel 3 menunjukkan bahwa, tingkat kecerahan pada konsentrasi $0,5 \%$ tidak berbeda nyata dengan konsentrasi $1,0 \%$. Bubuk bunga kenikir yang dihasilkan dari perlakuan perendaman dengan konsentrasi $0,5 \%$ tidak berbeda dengan konsentrasi $1,0 \%$ memiliki tingkat kecerahan tertinggi, hal ini berkaitan dengan kadar karotenoid pada perlakuan $0,5 \%$ menghasilkan kadar karotenoid terendah. Hal ini dikarenakan konsentrasi larutan asam laktat rendah, kurang dapat mencegah reaksi oksidasi sehingga bubuk bunga kenikir yang 
dihasilkan memiliki karotenoid rendah dan tingkat kecerahan lebih tinggi. Kandungan pigmen yang tinggi seperti karotenoid mempengaruhi tingkat kecerahan menjadi semakin rendah begitu juga sebaliknya (Khuluq et al., 2007).

Tabel 3. Nilai rata-rata tingkat kecerahan $\left(\mathrm{L}^{*}\right)$ pada perlakuan konsentrasi asam laktat dan lama perendaman.

\begin{tabular}{ccccc}
\hline Konsentrasi & \multicolumn{3}{c}{ Lama Perendaman (menit) } & Rata-rata \\
\cline { 2 - 5 } Asam Laktat $(\%)$ & 60 & 90 & 120 & \\
\hline 0,5 & 44,68 & 43,56 & 43,50 & $43,91 \pm 1,01^{\text {a }}$ \\
1,0 & 44,07 & 40,57 & 42,20 & $42,28 \pm 0,70^{\text {a }}$ \\
1,5 & 41,06 & 38,23 & 39,32 & $39,53 \pm 1,70^{\mathrm{b}}$ \\
\hline
\end{tabular}

Rata-rata $\quad 43,27 \pm 2,60^{\mathrm{a}} \quad 40,79, \pm 0,55^{\mathrm{ab}} \quad 41,67 \pm 0,26^{\mathrm{b}}$

Keterangan: Huruf yang berbeda di belakang nilai rata-rata pada baris atau kolom yang sama menunjukkan adanya perbedaan yang nyata $(\mathrm{P}<0,05)$.

\section{Tingkat kemerahan ( $\left.a^{*}\right)$}

Hasil analisis keragaman menunjukkan bahwa perlakuan konsentrasi asam laktat berpengaruh nyata $(\mathrm{P}<0,05)$ perlakuan lama perendaman dan interaksi berpengaruh tidak nyata $(\mathrm{P}>0,05)$ terhadap tingkat kemerahan $\left(a^{*}\right)$ bubuk bunga kenikir marigold. Nilai $\left(a^{*}\right)$ menyatakan tingkat warna hijau sampai merah dengan kisaran -100 sampai +100 . Nilai rata-rata dari tingkat kemerahan $\left(\mathrm{L}^{*}\right)$ dapat dilihat pada Tabel 4.

Tabel 4. Nilai rata-rata tingkat kemerahan $\left(a^{*}\right)$ pada perlakuan konsentrasi asam laktat dan lama perendaman.

\begin{tabular}{ccccc}
\hline Konsentrasi & \multicolumn{3}{c}{ Lama Perendaman (menit) } & Rata-rata \\
\cline { 2 - 4 } Asam Laktat (\%) & 60 & 90 & 120 & \\
\hline 0,5 & 24,23 & 25,40 & 26,30 & $15,31 \pm 0,88^{\mathrm{b}}$ \\
1,0 & 26,48 & 26,87 & 27,38 & $26,91 \pm 1,65^{\mathrm{ab}}$ \\
1,5 & 28,27 & 29,02 & 29,15 & $28,81 \pm 1,90^{\mathrm{a}}$ \\
\hline Rata-rata & $26,33 \pm 2,68^{\mathrm{a}}$ & $27,09 \pm 0,69^{\mathrm{a}}$ & $27,61 \pm 1,06^{\mathrm{a}}$ &
\end{tabular}

Keterangan : Huruf yang berbeda di belakang nilai rata-rata pada baris atau kolom yang sama menunjukkan adanya perbedaan yang nyata $(\mathrm{P}<0,05)$.

Tabel 4 menunjukkan bahwa rata-rata tingkat kemerahan $\left(a^{*}\right)$ bubuk bunga kenikir semakin meningkat seiring peningkatan konsentrasi asam laktat, yang juga mempengaruhi tingkat kemerahan menjadi semakin tinggi. Kadar karoten yang dihasilkan dari perlakuan asam laktat konsentrasi 0,5\% dengan konsentrasi $1,5 \%$ berbeda nyata sedangkan konsentrasi asam laktat $0,5 \%$ dengan $1,0 \%$ berbeda tidak nyata demikian pula konsentrasi asam laktat $1,0 \%$ dengan $1,5 \%$ berbeda tidak nyata. Perlakuan lama perendaman berbeda tidak nyata namun memiliki kecenderungan tingkat kemerahan yang meningkat seiring peningkatan lama waktu perendamamn. Hal ini di sebabkan oleh semakin lama perendaman akan dapat menghambat kerusakan karotenoid. Tingkat kemerahan $\left(a^{*}\right)$ dipengaruhi oleh banyak kandungan pigmen yang memberikan warna merah seperti karotenoid (Satriyanto et al., 2012).

\section{Tingkat kekuningan (b*)}

Hasil analisis keragaman menunjukkan bahwa perlakuan konsentrasi asam laktat berpengaruh nyata $(\mathrm{P}<0,05)$, sedangkan perlakuan lama perendaman berpengaruh tidak nyata $(\mathrm{P}>0,05)$ terhadap tingkat kekuningan $\left(b^{*}\right)$ bubuk bunga kenikir marigold. Nilai $\left(b^{*}\right)$ menyatakan tingkat warna biru sampai kuning dengan kisaran -100 sampai +100 . Nilai rata- 
rata tingkat kekuningan $\left(\mathrm{b}^{*}\right)$ dapat dilihat pada

Tabel 5.

Tabel 5. Nilai rata-rata tingkat kekuningan $\left(b^{*}\right)$ pada perlakuan konsentrasi asam laktat dan lama perendaman.

\begin{tabular}{ccccc}
\hline Konsentrasi & \multicolumn{3}{c}{ Lama Perendaman (menit) } & Rata-rata \\
\cline { 2 - 5 } Asam Laktat (\%) & 60 & 90 & 120 & \\
\hline 0,5 & 50,33 & 49,48 & 50,14 & $49,98 \pm 0,97^{\mathrm{b}}$ \\
1,0 & 51,06 & 51,37 & 50,98 & $51,13 \pm 1,34^{\mathrm{ab}}$ \\
1,5 & 51,14 & 51,93 & 52,67 & $51,91 \pm 0,97^{\mathrm{a}}$ \\
\hline Rata-rata & $50,84 \pm 0,43^{\mathrm{a}}$ & $50,92,00,50^{\mathrm{a}}$ & $51,26 \pm 2,35^{\mathrm{a}}$ &
\end{tabular}

Rata-rata $\quad 50,84 \pm 0,43^{\text {a }} \quad 50,92, \pm 0,50^{\text {a }} \quad 51,26 \pm 2,35^{\text {a }}$

Keterangan: Huruf yang berbeda di belakang nilai rata-rata pada baris atau kolom yang sama menunjukkan adanya perbedaan yang nyata $(\mathrm{P}<0,05)$.

Tabel 5 menunjukkan bahwa tingkat kekuningan tertinggi diperoleh dari bubuk bunga kenikir dengan perlakuan konsentrasi asam laktat 1,5\% tetapi tidak berbeda dengan tingkat kekuningan asam laktat konsentrasi $1,0 \%$. Tingkat kekuningan yang diperoleh dari perlakuan konsentrasi $1,5 \%$ dan $1,0 \%$ berbeda nyata dengan tingkat kekuningan yang diperoleh dari konsentrasi 0,5\%. Tingkat kekuningan berkaitan dengan kadar karotenoid dalam bubuk bunga kenikir, semakin tinggi kadar karotenoid maka tingkat kekuningan akan semakin meningkat. Hasil ini didukung oleh penelitian Aristyanti et al. (2017) tentang ekstraksi karotenoid dari bunga kenikir yang menunjukkan semakin tinggi kadar karotenoid maka tingkat kekuningan juga semakin tinggi. Karotenoid merupakan pigmen alami berwarna merah, kuning atau oranye (Gross, 1991). Perlakuan lama perendaman berbeda tidak nyata namun tingkat kekuningan cenderung meningkat seiring peningkatan lama waktu perendamamn. Hal ini disebabkan oleh semakin lama perendaman akan dapat menghambat kerusakan karotenid sehingga dapat mempertahankan karotenoid.

\section{KESIMPULAN}

\section{Kesimpulan}

Berdasarkan penelitian yang telah dilakukan maka dapat disimpulkan beberapa hal sebagai berikut :

1. Perlakuan konsentrasi asam laktat berpengaruh terhadap kadar total karotenoid, tingkat kecerahan (L*), tingkat kemerahan $\left(\mathrm{a}^{*}\right)$ tingkat kekuningan $\quad\left(b^{*}\right)$ tetapi tidak berpengaruh nyata terhadap kadar air. Perlakuan lama perendamanti tidak berpengaruh nyata terhadap kadar total karotenoid, tingkat kecerahan $\left(\mathrm{L}^{*}\right)$, tingkat kemerahan $\left(\mathrm{a}^{*}\right)$, tingkat kekuningan $\left(b^{*}\right)$ dan kadar air.

2. Perlakuan perendaman dengan konsentrasi $1,5 \%$ dan lama perendaman 90 menit merupakan perlakuan terbaik untuk menghasilkan bubuk bunga kenikir dengan karakteristik yaitu kadar air 16.71, kadar total karotenoid tertinggi 18,77\%, tingkat kecerahan (L*) 38,23, tingkat kemerahan $\left(a^{*}\right)$ 29,02, tingkat kekuningan (b*) 51,93.

\section{Saran}

Berdasarkan hasil penelitian ini dapat disarankan beberapa hal sebagai berikut :

1. Sebelum bunga kenikir diekstraksi perlu dilakukan perlakuan perendaman dengan 
asam laktat konsentrasi 1,5\% dan lama perendaman 60 menit.

2. Perlu dilakukan penelitian lanjutan seperti ekstraksi dan enkapsulasi agar mendapatkan ekstrak pewarna yang dapat diaplikasikan ke dalam bahan pangan.

\section{DAFTAR PUSTAKA}

Aristyanti, N.P.P., N.M. Wartini dan I.B.W. Gunam. 2017. Rendemen dan karakteristik ekstrak pewarna bunga kenikir (Tagetes erecta L.) pada perlakuan jenis pelarut dan lama ekstraksi. Jurnal Rekayasa dan Manajemen Agroindustri. 5(3):13-23.

Effendi, S. 2009. Teknologi Pengolahan dan Pengawetan Pangan. Cetakan Kesatu. Alfabeta, Bandung.

Gross J. 1991. Pigments in Vegetables, Chlorophyls and Carotenoids. Van Nostrand Reinhold, New York.

Handelman, G.J. 2001. The evolving role of carotenoids in human biochemistry. Nutrition $17: 818-822$.

Khuluq, A. D., S. B. Widjanarko dan E.S. Murtini. 2007. Ekstraksi dan stabilitas betasianin daun darah (Alternanthera dentata) (Kajian Perbandingan Pelarut Air:Etanol dan Suhu Ekstraksi). Jurnal Teknologi Pertanian. 8(3): 172-181.

Muchtadi, D. 1989. Evaluasi Nilai Gizi Pangan. Departemen Pendidikan dan Kebudayaan Direktorat Jenderal Pendidikan Tinggi Pusat Antar Universitas Pangan dan Gizi. Institut Pertanian Bogor, Bogor.
Prabasini, H., D. Ishartani, dan D. Rahadian. 2013. Kajian sifat kimia dan fisik tepung labu kuning (Curcurbita moschata) dengan perlakuan blanching dan perendaman dalam Natrium Metabisulfit $\quad\left(\mathrm{Na}_{2} \mathrm{~S}_{2} \mathrm{O}_{5}\right)$ Jurnal Teknosains Pangan. 2(2): 93-102.

Priyanka, D., T. Shalini, and V.K. Navneet. 2013. A Brief study on marigold (Tagetes Species) a review. International Research Journal of Pharmacy. 4(1):43-48.

Satriyanto, B., S.B. Widjanarko, dan Yunianta. 2012. Stabilitas warna ekstrak buah merah (Pandanus conoideus) terhadap pemanasan sebagai sumber potensial pigmen alami. J. Teknol Pertanian. 13(3):157168.

Sudarmadji, S., B. Haryono dan Suhardi. 1997. Analisa Bahan Makanan dan Pertanian. Penerbit Liberty, Yogyakarta.

Vasudevan, P., S. Kashyap and S. Sharma. 1997. Tagetes: A Multipurpose Plant.

Bioresource Technol. 6(2):29-35.

Weaver, C. 1996. The Food Chemistry Laboratory. CRC Press, Boca Raton, New York, London, Tokyo.

Yanuwardana., Basito dan D. R. A. Muhammad. 2013. Kajian karakteristik fisikokimia tepung labu kuning (cucurbita moschata) termodifikasi dengan variasi lama perendaman dan konsentrasi asam laktat. Jurnal Teknosains Pangan. 2(2):75-83. 